\title{
Pregnancy Partner
}

National Cancer Institute

\section{Source}

National Cancer Institute. Pregnancy Partner. NCI Thesaurus. Code C100811.

An individual who provides support to a pregnant individual. 